\title{
HAVE WE FORGOTTEN THE 7TH ECUMENICAL COUNCIL? ERRORS CONCERNING THE WORSHIP OF THE ICONS IN CONTEMPORARY ROMANIAN LITURGICAL PRACTICE
}

\author{
Prof. Ph.D. Dumitru A. VANCA, \\ „1 Decembrie 1918” University in Alba Iulia, \\ ROMANIA \\ E-mail: dumitru.vanca@uab.ro
}

\begin{abstract}
In marked contrast to the orthodox theology and practice of worshiping holy icons, as taught by the Church as a result of the iconoclastic debate in 8thcentury (Nicaea, 787), Romanian Christians attitudes and practices today are not only erroneous, but sometimes even contradict the decisions and teaching of the Holy Fathers. These deviations also have affected the currently practice of worshiping. For example, the Euchologion endorsed for the Romanian Church today stipulates that icons are blessed in a liturgical service (I think can be used both words; during, but also through), although this was rejected by the Fathers and by usual customs of the 8th century.

Another misunderstanding of the Tradition spirit in the official worship of the Church are irregularities in Christians' private life of faith. Various practices here seem to reflect ideas which are not in line with the doctrine of the Orthodox Church. For example, many faithful place the icons in their homes to hinge on the dimensions of the wall and not always on the east side walls of the house. Sometimes they arrange icons in a way that makes it impossible to touch and kiss them, thus deviating from what the most important Fathers who defended the worship of icons have prescribed. Sometimes the faithful intermingle family pictures with their icons, thus misleading onlookers to stipulate a misplaced "holiness" for such family members.
\end{abstract}

Keywords: icons; today liturgical practice; wrong attitudes; liturgy;

\section{INTRODUCTION}

Apart from some specialists, for whom the sacred images were just an object of study, the theology of the icons remained totally unknown to the Western world, both Catholic and Protestant. Only at the beginning of the previous century a group of well established theologians, especially Russians (Florenski ${ }^{1}$, Ouspensky ${ }^{2}$, Evdokimov ${ }^{3}$ etc.) have begun to introduce them to the world from a different perspective. Due to their efforts, orthodox

\footnotetext{
${ }^{1}$ P. Florenski, On the Icon, in Eastern Church Review 8 (1976) 11-37; Idem, Iconostasul trad. rom. B. Buzilă, Bucharest, Edit. Anastasia, 2009.

${ }^{2}$ L. Uspensky, The Theology of the icon trad. rom. E. Drevici, Cluj Napoca, Edit. Renașterea/Edit. Patmos, 2005.

${ }^{3}$ P. Evdokimov, The Art of the icon: a theology of beauty, trad. rom. G. Moga și P. Moga, Bucharest, Edit. Sophia, 2014.
} 
theology would shed some light on one of its much-ignored aspects - the theology of the icons - an issue which gave cohorts of saints to the Church and has dogmatically presented the last doctrinal problems before the Great Schism. Once seen as ugly, unesthetic and obviously far from the realistic anatomy of the well known masterpieces of Da Vinci, Michelangelo, Rafael and Tizian, the image of Christ the Lord, of the Virgin or of other saints were now seen in a new light. Beyond the snobbish and exotic curiosity of some, beyond the scientific interest of others, the icons were revealing a spiritual world full of unknown depths to the open-hearted one. Some Western Theology Faculties begin to include courses of iconology in their curriculum and books about the theory and the theology of the icons will appear. The ascetic and dark images, which were filiform and without relation to time, started to replace the paintings of the Renaissance which you were accustomed to in the catholic monasteries, offices and houses.

The Western 'iconological revolution' reached Romania quite late. With a few small exceptions of theologians who had studied in Western Europe, by the '80s the range of studies and articles related to the theology of the icons was quite limited, - presenting a marked contrast to the reality from the 'field'; the houses of the Romanians, especially in Transylvania, which continued to be filled with polygraphic copies of well known Renaissance paintings. Is there anyone who does not remember of the Holy Family, doves and the Christ child, of Coronatio Virginis and of Christ praying in the garden of Gethsemane? And although you can still find some of these copies in many homes, the connection which Romanians have with the authentic icons is beginning to change.

But, even if theologians and scholars have gained a better understanding, the devotional practices as well as the connection, which Christians have with the icons, does not always reflect the correct attitude, according to the theology developed by the Elders of 8th and $9^{\text {th }}$ centuries, but it is almost opposite in some situations.

\section{THE CONTRADICTION BETWEEN DOCTRINE AND CONTEMPORARY PRACTICE}

In order to demonstrate this contradiction between the doctrine, proclaimed and upheld in the official literature of the Romanian Orthodox Church, and the contemporary liturgical practice, we will analyze a few examples.

\section{The mistaken quest for consecration}

When acquiring an icon, the majority of the Romanians hasten to the priest and ask for the consecration of it; sometimes, even the priest and the bishops who are giving icons to the believers, make sure that these have the stamp 'consecrated', to ascertain its sacramental power. This custom is totally contrary to the old practice of the Church.

As Father Stephan Bigham makes clear ${ }^{4}$, this is a catholic novelty, introduced in the liturgical cursus through Petru Movilă's Euchologion (1646), which was contaminated by Western practices. This Euchologion proposes five consecration prayers ${ }^{5}$, according to the

\footnotetext{
${ }^{4}$ S. Bigham, ,Does the Blessing of Icons Agree with or Contradict the Tradition of the Orthodox Church?”, în Orthodox Art Journals, at: https://www.orthodoxartsjournal.org/does-the-blessing-of-icons-agree-with-or-contradictthe-tradition-of-the-orthodox-church/ (accesat în 4.11.2017) Translated in Romanian in Pemptousia: "Sfinţirea" icoanelor: o practică în contradicţie cu Tradiţia Bisericii - 2, Available online at http://www.pemptousia.ro/2013/10/sfintirea-icoanelor-o-practica-in-contradictie-cu-traditia-bisericii-partea-a-doua/ (acces at în 4.11.2017). The same study, with small changes was published in the volume Ce este icoana ?, Edit. Reîntregirea, Alba Iulia, 2009.

${ }^{5}$ The ritual proposed by Petru Movilă, identical to all five types of prayers, is amply structured within a complex ritual with blessing and conclusion, a psalm, a complex prayer and a prayer with the head bowed down, suitable
} 
importance of the persons they represent: of the Holy Trinity, of Christ and Festive days, of Virgin Mary, of the saints and of the consecration of the icons with more scenes. The national churches, which where under the influence of Slavonic languages, have partially or totally introduced these consecration prayers ${ }^{6}$, while the Churches under Greek influence introduced through the Euchologion from 1730, only one small consecration prayer, associated with anointing the four corners of the icon.

This practice of consecrating some particular objects, among which we find the icons as well, entirely contradicts the 'orthodox solution' approved during the time of the iconoclast dispute, - a solution which entirely and undoubtedly repudiates the liturgical practice proposed in the current Euchologion. At that time, the iconodules answered to iconoclast accusations by pointing out that the Church doesn't even have consecration prayers, through which the icons achieve a sacred character: neither the Cross, nor the Holy Gospel and the icons need consecration, as their holiness comes from within, and from their relation with archetype:

'Many of the sacred objects which we have do not need a consecration prayer because their own name claims that they are holy and full of grace. As a result, we honour and we kiss them as they are venerable objects. And so, even without a consecration prayer we are praising the sign of the life giving Holy Cross. Because its shape is suffice enough for us to receive the blessing, with the honour which we give it when we do its cross sign on our foreheads; and even when we make the sign of the cross with our fingers in the air, like a seal, we hope that it will banish all the devils. We do the same when we write the name of a saint on an icon, and so transferring the honour of the prototype onto the icon; while kissing it and praising it, we become part of its holiness (the prototype); moreover, we kiss different consecrated objects which we have, in doing so we are expressing our hope that we will receive their blessing' 7

When the trend of consecration prayers reached Greece as well in the 19th century, Nicodemus the Hagiorite (From the Athos Mount) opposed it; his view reflects the fact that this practice was a new and unknown phenomenon to the Greek texts printed in the 17th century and that it wasn't wide spread. His arguments were simple, clear and according to what had been established in the 8th century, decisions which Nicodemus quotes:

'1). It is not necessary to anoint the holy icons with myron (or chrism oil), nor to have them sanctified by the bishop with special prayers: because we do not adore the holy icons because they are anointed or have had prayers said over them, but irrespectively, as soon as we lay eyes on a holy icon, without pausing to examine into the possibility of its having been anointed or having had a special prayer said over it, we at once proceed to pay adoration to it both on the account of the name of the Saint and on the account of the likeness it bears to the original. That is why in Act 6 of the present Council, the Council of the iconomachs in the region of Copronymus disparaged the holy icons by asserting that the name of the pictures neither has any sacred prayer sanctifying it, in order that from what is common it might be transferred to what is holy, but that, on the contrary, it (st. the picture) remains common and

troparia and a supplication with an epiclesis shape.

${ }^{6}$ For example, the first Romanian euchologions (Dosoftei - Iaşi, 1681; Zoba - Alba Iulia, 1689; Mitrofan - Buzău, 1702; Antim - Râmnic, 1706) did not contain these prayers. The version from Bucharest, 2002, shows only three types of consecrations ( of Christ and of Festive days, of Virgin Mary and of saints), while the last version (Bucharest, 2013) adds the one for the Holy Trinity.

${ }^{7}$ MANSI, Sinodul de la NICEEA II, XIII, APUD Icon and Logos: Sources in Eighth-Century Iconoclasm, Daniel Sahas (ed.), Toronto, Ontario, University of TORONTO Press, 1986. 
dishonorable (i.e., not entitled to honor), just as the painter made it. To these allegations the holy Seventh Council replied through Deacon Epiphanius, by asserting that it did not say that any special prayer is said over the icons, but said that like many other sacred objects they were incapable of receiving (benefit from) any special prayer; but, on the contrary from their very name they are replete with grace and sanctity, in the same way that the shape of the vivifying Cross is, which is entitled to veneration and adoration among us in spite of the fact that it is made without having any special prayer said over it; and we believe that with its shape alone we acquire sanctity, and with the adoration which we pay to it, and the marking of it upon our forehead, and the seal of it which is made in the air with the hope of chasing away the demons. Likewise, in the same way that we have many sacred vessels, and kiss and embrace them fondly, and hope to receive sanctity from them, in spite of the fact that they have not had any special prayers said over them, so and in like manner by fondly kissing and embracing and paying honorary adoration to a holy icon that has not had special prayers said over it we partake of sanctity, and are analogically lifted up and carried back to the honor of the original through the name of the icon. But if the iconomachs cannot assert that the sacred vessels are dishonorable and common because of their not having had any special prayers said over them for the purpose of sanctifying them, but are just as the waver, the painter, and the goldsmith finished them, yet they regard them as holy and precious; in the same way they ought to regard the venerable icons as holy and precious and sacred even though they have not had any special prayers said over them to sanctify them.

2).The holy icons do not need any special prayer or any application of myron (or chrism), because, according to Dositheus (p. 658 of the Dodecabiblus) it is only the Papists (or Roman Catholics) that perpetrate the iniquity of qualifying pictures with certain prayers and devotions. For they boast that the Pope manufactures pictures from pure wax, holy oil, and water of sanctification, and that he reads marvellous prayers over them, and that because of these special features these pictures perform miracles (just as they lyingly state that Leo III sent such a picture to King Charles of France, and he reverenced it; and that Pope Urban sent another picture to John Paleologus, and this one was honored with a litany in the Church). Do you see that the prayer which is read over holy pictures is a Papal affair, and not Orthodox; and that it is a modern affair, and not an ancient one? For this reason no such prayer can be found anywhere in the ancient manuscript Euchologia. In fact, we have noticed that this prayer is not even found in Euchologia printed only a hundred years ago! 3). It becomes evident that holy icons do not need any special prayer or application of myron (i.e., holy oil), because the pictures painted on the walls of churches, and in their naves and in their aisles, and in general in streets and on doors, and on the sacred vessels, are never anointed with myron and never any special prayer said over them, and yet, in spite of this, adoration is paid to them relatively and honorarily by all on account of the likeness they bear to the originals. [...]This same view is confirmed also by Dositheus (p. 655 of the Dodecabiblus). Plato the very learned Archbishop of Moscow notes in connection with the second commandment of the Decalogue in his Orthodox Catechism that one must not think one picture holier than another, nor expect more from one picture than from another, or place greater trust in one than in another.' 8 8 'The Rudder', Prolegomena on the Ecumenical Seventh Council, Available online at :
http://s3.amazonaws.com/orthodox/The Rudder.pdf (Accessed: $22 / 04 / 2018$ ), pp 419-420 


\section{The common procedure of placing the icons contravenes the Church doctrine regarding the adoration of the holy icons \\ The parietal placement of the icons sometime excludes their role for worship}

As we know, the function of the holy icons is: charismatic and liturgical, doctrinaire and apologetical, anamnetic-historical and esthetical. Unfortunately, the way we place the icons in the public and domestic spaces, reveals an attitude which overturns the hierarchy of the attributes and of the liturgical functions of the holy icons. Although the aesthetic function of the icons is considered to be secondary, it often prevails. Therefore, the icons are placed according to the available space, and not according to liturgical concerns. We are often more concerned about the aesthetical 'balance' when placing the icon on the wall than the fact that the Holy Fathers imposed that the icon shall be venerated through touch and kissing. This can be seen in large spaces such as conference rooms, classrooms etc., where the icons are placed medially at 4-5 metres height and where they can only be seen; this makes impossible the idea of touching or kissing them.

\section{The parietal placement of the icons excludes their orienting role}

Often a further aspect of the functional-liturgical character of the icons is forgotten their orientation. The orientation towards East during prayer was a rigorous ${ }^{9}$ practice within the primary Church and the axial orientation of the church (pronaos, naos, altar) was suggesting a progressive movement towards sunrise. Even the houses in the villages had the icon placed 'on the eastern wall'. This liturgical geography referred to the transcendence of time and through this entering a metaphysical dimension, testifying to the eschatological hope of the Church. Nowadays, many of the icons which 'decorate' the public and domestic spaces, are placed according to the pragmatic function of the room and disregard the old principle of liturgical orientation. The liturgical orientation towards East 'disappeared,' making room for an aesthetical pragmatism. Today, we can see that the way in which the icons are displayed in the private and public spaces, mostly reveals our aesthetical needs, because in most of the situations the icons are placed according to the location of the window, the door, the furniture etc., the icon is no longer orientated in space but it only has a decorative function. Funnily enough, sometimes the prayer at the table is said facing the plates, the icons from the classrooms are placed above the blackboard or the teacher's desk. In consequence, we are facing a new authority and a new spiritual orientation principle: the food, the desk, and the emptiness.

\section{The parietal placement of the icons discounts the sacramental hierarchy}

Even the way in which we combine different sacred images is not always the most appropriate. For example, in some institutional spaces (deanearies, bishoprics, parsonages), the icons of Christ and Virgin Mary, and even the sign of the Holy Cross, is flanked by portraits of ruling bishops and metropolitans. This way of displaying the images should be avoided because it brings a sort of leveling, of homogenisation of the sacredness. No bishop would argue the fact that his image should be placed on a different wall than the one where the icon of Christ of Virgin Mary is positioned, because he is aware of his own humbleness as well as of the flattery of his inferiors. This is why we believe that more discernment is needed when choosing the place where the icons would be set. It would be wise to never display the images of the living on the same wall with the holy icons, not even to mention that placing them at the same level is forbidden.

\footnotetext{
${ }^{9}$ Uwe Michael Lang, Turning Towards the Lord: Orientation in Liturgical Prayer, San Francisco, California, Ignatius Press, 2004.
} 


\section{Desacralisation through the abuse of usage}

The Quinisext Council (692 AD), through its 73rd Canon, imposed the interdiction of the cross sign being displayed on the floor:

'Since the life-giving cross has shewn to us Salvation, we should be careful that we render due honour to that by which we were saved from the ancient fall. Wherefore, in mind, in word, in feeling giving veneration ( $\pi \rho 0 \sigma \kappa v ́ v \eta \sigma \mathrm{w})$ to it, we command that the figure of the cross, which some have placed on the floor, be entirely removed therefrom, lest the trophy of the victory won for us be desecrated by the trampling under foot of those who walk over it. Therefore those who from this present represent on the pavement the sign of the cross, we decree are to be cut off.' 10

By taking into account the dogmatic essence of this Canon ${ }^{11}$, we shall observe the intention of the participants at the council to protect the Christian symbols from profanation by being displayed in unsuitable places. For this reason, we should reconsider our attitude towards the frequent reproductions which appear in newspapers - even in the daily and periodical papers of different dioceses of the Romanian Patriarchate- or by hanging them in spaces where frequently indecent attitudes and actions are taking place. Not one single Christian would feel comfortable knowing that some icons found in the newspapers would end up in the bin. The time when Christians used to cut the holy images from the magazines is long gone, but the reproduction of bilions of holy images seen everywhere, is diluting the perception of their sacredness.

Although some say that the reproductions from the newspapers are not icons, the meaning which the Holy Fathers gave to the word eikon is a general reference to image; for this reason, the Greeks have always used the term eikon together with the syntagma 'ta aghia' ( the holy icons). Even if in current Romanian language there is a difference between image and icon, we need to acknowledge the fact that the icon is not just a portable image, painted on wood but it is the holy image reproduced through any technical methods and on any kind of material. Or this is what we should understand from St Theodore Studite affirmation: 'Based on the icon's nature, we call its visible reality not 'Christ', not even 'image of Christ', but wood, paint, gold, silver, or some other material employed. Yet based upon the image of the person depicted, the icon is called 'Christ' or 'image of Christ'; 'Christ' because of the identity in name, 'image of Christ' because of the relationship. '12

These considerations must have motivated the prohibition of displaying holy images on clergy robes, excepting the ones wore by bishops.

10 P. Schaff, The Canons Of The Council in Trullo; Often Called The Quinsext Council, at: http://www.documentacatholicaomnia.eu/03d/0691-

0691, Synodum_Constantinopolitanum,_Canones_\%5BSchaff\%5D,_EN.pdf (Accessed: 22.04.2018) p. 570.

11 Nikolai Afanasiev observed that we should never idolize the canons; that they should be interpreted in their dogmatic essence and not in their historical and temporal forms, which are difficult to be totally comprehended by all generations. " The 'Canons are shaping the dogma under the manners of some norms which must be followed in the life of the church to be in accordance with the dogmatical values. The Canons are some sort of canonical explanation of the dogmas at a certain point in Church history; they are in fact an old source, a code of conduct of the life of the Church, revealing the truth on the order of the life in Church, but rather following the historical existence than showing the truth in its absolute forms.' („Canoanele Bisericii: schimbabile sau neschimbabile?”, în Jivoie Predanie, Paris, 1936, YMCA Press, pp. 82-96 (trad. I. Nistea, disponibil pe http://www.nistea.com/Afan2.htm, accessat la 1.11.2017)

${ }^{12}$ D. Clayton, The $7^{\text {th }}$ Ecumenical Council and St Theodore the Studite on Holy Icons, Available online at: https://www.scribd.com/doc/31367329/The-7th-Ecumenical-Council-and-St-Theodore-the-Studite-on-Holy-Icons (Accessed: 22/04/2018) p. 6. 
This should be the reason why we must pay more attention when choosing to reproduce these holy images of Christ, Virgin Mary and other saints on either book covers, newspapers, magazines, or even as 'icons' given to the faithful. I don't even want to mention the fact that I have seen holy images on cuffs and pens, on paper bags, on touristic materials, on folders etc. I believe that displaying the holy images on such materials is making them seem vulgar and this only created controversies which would be detrimental for the cult of the holy icons. Although these reproductions seem to highlight Christ's charismatic presence within our life, we should be more considerate when allowing for the icons to be hanged in clubs, restaurants or in any other place where these would not be truly worshiped. Otherwise, the ones who displayed them in such places, must see them more as talisman, or as a object which would banish evil omens.

\section{CONCLUSION}

What can we do? In order for errors not to be perpetuated among the faithful, the Church, be it institutionally - through decisions and norms, or particularly - through the pastoral mission of bringing awareness to the clergy and the faithful, must intensify the doctrinal catechesis, for a correct and full understanding of the Church teaching on icons. Is it not only through the word but through the images as well, that errors are transmitted, - as obvious from the way in which the modern world is ruled by images. Of course, we cannot go back in time. Even if we do so, what is the reference point we choose? The Church cult before the iconoclasm, the Golden century or the Church of the Gospel? The Church is a living organism; it is dynamic; sometimes with setbacks and even errors. But our duty is that, once we identify these errors, to eliminate these errors. The faith must be in conformity with the practice and vice versa: Lex orandi lex credendi.

\section{Some clear, practical and simple decisions must be taken:}

As to the mis-practice of consecrating icons, the fact that people have become accustomed to such services makes it un-advisable for the Holy Synod to correct matters by returning to the old liturgical practices of before the $17^{\text {th }}$ century and to purify the Euchologion from all the 'altered' services. Fr. Bigham therefore proposes instead a renaming, for example as 'The office of commencement of an icon', or 'The office of the first investiture', or something like that ${ }^{13}$. Here the epiclesis formula should either be removed or replaced with one that would relate to the teaching of the Church, according to which the icon is sanctified through the relation with the prototype and through the registration of its name.

As to our dealing with icons in daily life, we shall

- advise the priests and the faithful on always placing the icons in their private homes, offices and public spaces on the eastern wall, the place towards which we need to be orientated during prayer;

- avoid the display of the icons of Christ, Virgin Mary etc. alongside the family photos, images with our bishops due to the duty we have of not to inducing the idea of placing them (the relatives, etc.) in the same sacred level;

- be reserved when we choose to print reproductions of icons in magazines and church periodicals, or on book covers, knowing that these reproductions are icons as well. The risk of them ending in the bin or being desecrated is too great.

${ }^{13}$ S. Bigham, idem. 


\section{BIBLIOGRAPHY:}

[1] *** Icon and Logos: Sources in Eighth-Century Iconoclasm, Daniel Sahas (ed.), Toronto, Ontario, University of Toronto Press, 1986;

[2] AFANASIEV, Nikolai, „Canoanele Bisericii: schimbabile sau neschimbabile?”, în Jivoie Predanie, Paris, 1936, YMCA Press, pp. 82-96 (rom.trans. by I. Nistea, available at http://www.nistea.com/Afan2.htm, accessed at 1.11.2018)

[3] Bigham S., „Does the Blessing of Icons Agree with or Contradict the Tradition of the Orthodox Church?", în Orthodox Art Journals, at: https://www.orthodoxartsjournal.org/does-the-blessing-oficons-agree-with-or-contradict-the-tradition-of-the-orthodox-church/ (accesat în 4.11.2017)

[4] BIGHAM, Stéphane, „Does the Blessing of Icons Agree with or Contradict the Tradition of the Orthodox Church?", in Orthodox Art Journals, available athttps://www.orthodoxartsjournal.org/does-the-blessing-of-icons-agree-with-or-contradict-thetradition-of-the-orthodox-church/ (accessed at 4.11.2018).

[5] Evdokimov P., The Art of the icon: a theology of beauty, trad. rom. G. Moga și P. Moga, Bucharest, Edit. Sophia, 2014.

[6] Florenski P., Iconostasul trad. rom. B. Buzilă, Bucharest, Edit. Anastasia, 2009.

[7] Florenski P., On the Icon, in Eastern Church Review, 8 (1976)

[8] Lang Uwe Michael, Turning Towards the Lord: Orientation in Liturgical Prayer, San Francisco, California, Ignatius Press, 2004.

[9] Molităvnic (Zoba ed.), Alba Iulia, 1689 (I ussed the new edition by Ana Dumitran, Alin-Mihai Gherman şi Dumitru A. Vanca, Alba Iulia, Reîntregirea, 2009).

[10] Molitfelnic (Antim ed.), Râmnic, 1706;

[11]Molitfelnic (Mitrofan ed.), Buzău, 1702;

[12] Molitfelnic (Official edition of the Holy Synod of Romanian Orthodox Church), Bucureşti, 2002;

[13] Molitvenic (Dosoftei ed.), Iaşi, 1681;

[14] Schaff P., The Canons Of The Council in Trullo; Often Called The Quinsext Council, at: http://www.documentacatholicaomnia.eu/03d/0691-

0691,_Synodum_Constantinopolitanum,_Canones_\%5BSchaff\%5D,_EN.pdf

(Accessed: 22.04.2018)

[15] Sfântul VASILE CEL MARE, Despre Sfântul Duh, în PG 32, col. 188 [trad. rom. C. Corniţescu, T. Bodogae, în PSB vol. 12, p. 79];

[16]St. Nicodim Aghioritul, Pidalion,, trad. rom. Mănăstirea Neamțu, 1844;

[17]Teodor STUDITUL, Iisus Hristos prototip al icoanei Sale. Tratatele contra iconomahilor (I, 11), Edit. Deisis, Alba Iulia, 1998.

[18] The canons of the orthodox Church available at http://nomocanon.com/canoanele-sinoadelorecumenice/ (accessed on 18.11.2018);

[19] Uspensky L., The Theology of the icon, trad. rom. E. Drevici, Cluj Napoca, Edit. Renașterea/Edit. Patmos, 2005. 